\author{
Agnieszka Stopińska-Pająk \\ Wyższa Szkoła Biznesu w Dąbrowie Górniczej \\ Wiceprezes ATA
}

\title{
Edukacja dorosłych w kontekście nauk społecznych i humanistycznych. Wprowadzenie do obrad
}

W maju 2016 roku - prawie równy rok temu - odbyliśmy w Zakopanem IX z kolei konferencję zorganizowaną przez Akademickie Towarzystwo Andragogiczne, podczas której podjęliśmy rozważania nad doświadczaniem i doświadczeniem dorosłości we współczesnym świecie. Świecie, w którym zostały podważone nie tylko różne tradycyjne sposoby praktyk społecznych, w tym i edukacyjnych, ale także nasze postrzeganie własnej dorosłości. Dzisiejsze spotkanie kontynuuje te rozważania, ogniskując je wokół aktywności dorosłych w edukacji, w jej różnych przejawach i kontekstach.

Tak jak nie ma już jednego wzorca dorosłości, i jak można za Jeanem Claude'em Kaufmanem powiedzieć, iż każdy może się wymyślić dowolnie oraz wielokrotnie, tak również nie ma jednego wzorca edukacji dorosłych. Dorosłość ma współcześnie niewątpliwie charakter polifoniczny, jest obarczona wymogiem ciągłego biograficznego konstruowania własnej tożsamości, a to z kolei wymaga wielokrotnego uczestnictwa w edukacji. Edukacji rozumianej nielinearnie, na każdym etapie życia oraz równoczesnego uczestnictwa w licznych i różnych jej formach, zarówno instytucjonalnych, jak pozainstytucjonalnych i nieformalnych. Powszechna edukacja dorosłych jest niewątpliwie fenomenem epoki ponowoczesnej, tak jak powszechna edukacja dzieci była wyznacznikiem epoki nowoczesnej.

Ten fenomen ponowoczesności sprawił, iż pojęcie edukacji dorosłych zostało przyjęte i włączone w dyskurs różnych dyscyplin naukowych - zajmuje się nim nie tylko andragogika - jest obecne w zasadzie we wszystkich naukach społecznych i humanistycznych, ale także biologicznych, przyrod- 
niczych, ekonomicznych i pozostałych. Edukacja dorosłych jest definiowana i ujmowana swoiście w kontekście każdej z tych dyscyplin. I chociaż na ogół wszyscy podkreślają, iż charakter zjawisk edukacji dorosłych wymaga spojrzenia wychodzącego poza ramy jednej dyscypliny, to jednak brak jest opracowań, w których dyskurs wokół edukacji dorosłych odzwierciedlałby ponaddyscyplinarne ujęcie. Także w obrębie andragogiki, chociaż jest to dyscyplina odwołująca się do dorobku różnych nauk, to jednak niejednokrotnie wręcz uzurpuje sobie wyłączne prawo do analizy, badań i interpretacji różnych zagadnień związanych z edukacją dorosłych. Nie jest to oczywiście problem samej andragogiki, także w obrębie innych nauk społecznych i humanistycznych, mimo uznania potrzeby interdyscyplinarnego czy multidyscyplinarnego widzenia różnych zjawisk społecznych, nadal koncepcja dyscyplinarnych granic organizuje myślenie badaczy. Dzisiaj nie wystarczają nam już te interdyscyplinarne ujęcia, gdyż one nadal zachowują, a nawet, jak niektórzy podkreślają, utrwalają podziały pomiędzy różnymi dyscyplinami, aczkolwiek niewątpliwie pozwalają widzieć określone zjawiska czy problemy z różnych perspektyw, przyczyniając się do pogłębienia wiedzy o określonym przedmiocie badań.

W dyskursie nauk społecznych i humanistycznych w coraz większym stopniu uznanie zyskuje podejście transdyscyplinarne, dające możliwość analizy przekraczającej granice poszczególnych dyscyplin. Spośród różnych, szczególnie ciekawe w tej kwestii jest stanowisko Mieke Bal, holenderskiej historyczki sztuki i literaturoznawczyni (Bal, 2012). Badaczka przekonująco uzasadnia potrzebę podejścia transdyscyplinarnego, które akcentuje płynność granic pomiędzy dyscyplinami, umożliwiając nieograniczone możliwości przenikania pojęć pomiędzy nimi. Jak podkreśla Bal, transdyscyplinarność zakłada, że przemieszczanie się danego pojęcia pomiędzy dyscyplinami nie ma żadnych barier, jest ono nieograniczone, płynne. Jedynie użyteczność dla nowego dyskursu, który pojawia się w obrębie danej dyscypliny stanowi uzasadnienie dla jego zastosowania (Burszta i in., 2012). Podejście transdyscyplinarne, jak pisze Bal, umożliwia pogłębienie samoświadomości danej dyscypliny, modyfikację metodologii i celów badawczych, a wreszcie uświadamia nam, że chociaż w różnych dyscyplinach dane pojęcie pełni bardziej czy mniej istotną rolę, to jednak przede wszystkim funkcjonuje pomiędzy i nie może być zawłaszczane przez żadną z nich (Kola, 2016). Mieke Bal formułuje na podstawie tych analiz koncepcję wędrowania pojęć (travelling concepts). „Badaczka definiuje je jako proces przemieszczania się konkretnych pojęć i kategorii badawczych z jednej dyscypliny do drugiej. Owo przemieszczanie nie ma jednak ani linearnego, ani statycznego charakteru: 
pojęcia stale ewoluują, zmieniając się pod wpływem metodologii dyscypliny, w której funkcjonują, a także pod wpływem konkretnych problemów badawczych. Równocześnie zmieniają także dyscyplinę, do której przywędrowały" (Tabaszewska, 2013, s. 121).

To znakomita koncepcja, w kontekście której można i należy opisywać edukację dorosłych. Edukacja dorosłych jest, jak sądzę, przykładem właśnie takiego wędrującego pojęcia, obecnego w różnych naukach. Analizy edukacji dorosłych w perspektywie tej kategorii mogą znacząco przyczynić się do ponowoczesnego dyskursu tak samego pojęcia i jego rozumienia, jak i jego zastosowań w różnorodnych praktykach edukacyjnych. Jest to znakomite narzędzie do badania ewolucji edukacji dorosłych także w obrębie samej andragogiki, a przede wszystkim uznania za Mieke Bal, że pojęcia nigdy nie są jednoznaczne, ale ich cechą jest płynność znaczeń (2013, s. 50). Stąd też i nasz zamysł wyrażony w ujęciu programu III Zjazdu. W trakcie obrad podejmować będziemy dyskurs nad edukacją dorosłych z różnych dyscyplinarnych perspektyw badawczych, a mianowicie: pedagogiki i seksuologii, socjologii, historii oraz ekonomii. Pozwoli to nam wszystkim, reprezentantom różnych dyscyplin zajmujących się edukacją dorosłych, przyjrzeć się, jak to pojęcie funkcjonuje $\mathrm{w}$ ramach konkretnej dyscypliny i co możemy $\mathrm{z}$ tego sposobu ujmowania włączyć do swojego obszaru badań i do własnego rozumienia, ale także - i to jest szczególnie istotne - jak ludzie dorośli, uczestnicy edukacji, postrzegają edukację, jakie imaginaria - jak za Charlesem Taylorem (2010) można byłoby określić - kształtują ich myślenie o edukacji. Jest to szczególnie ważne dla praktyk badawczych realizowanych w obrębie andragogiki.

Kończąc, należy za Mieke Bal podkreślić, iż wędrowanie pojęć, ich przemieszczanie się poprzez różne dyscypliny jest przede wszystkim warunkowane ich zakorzenieniem w naszych praktykach kulturowych.

Życzę Państwu owocnych obrad i aby to spotkanie było podstawą naszego nieustającego dyskursu wokół edukacji dorosłych w zmieniającym się płynnym, ale też, jak pisze Przemysław Czapliński (2016), lotnym świecie.

\section{Bibliografia}

Bal M. (2012), Wędrujące pojęcia w naukach humanistycznych: Krótki przewodnik, tłum. Marta Bucholc, Warszawa. 
Burszta W. J., Zeidler-Janiszewska A. (2012), Poza akademickimi podziałami. Wędrowanie z Mieke Bal - wstęp (w:) M. Bal, Wędrujące pojęcia w naukach humanistycznych: Krótki przewodnik, tłum. Marta Bucholc, Warszawa.

Czapliński P. (2016), Poruszona mapa. Wyobraźnia geograficzno-kulturowa polskiej literatury przełomu XX i XXI wieku, Kraków.

Kola A. M. (2016), Recepcja terminu „wychowanie” na łamach czasopisma „Praca Socjalna”, „Wychowanie w Rodzinie”, nr 1, T. XIII.

Tabaszewska J. (2013), „Wędrujące pojęcia”. Koncepcja Mieke Bal - przykład inter-czy transdyscyplinarności? „Studia Europaea Gnesnensia”, nr 8.

Taylor Ch. (2010), Nowoczesne imaginaria społeczne, tłum. Adam Puchejda, Karolina Szymaniak, Kraków. 